\title{
Comparison of diversity and composition of macrofungal species between intensive mushroom harvesting and non- harvesting areas in Oaxaca, Mexico
}

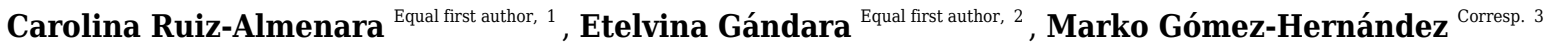 \\ ${ }^{1}$ CIIDIR Unidad Oaxaca, Instituto Politécnico Nacional, Santa Cruz Xoxocotlán, Oaxaca, México \\ 2 Facultad de Ciencias Biológicas, Benemerita Universidad Autónoma de Puebla, Puebla, Puebla, Mexico \\ ${ }^{3}$ CONACYT-CIIDIR Unidad Oaxaca, Instituto Politécnico Nacional, Santa Cruz Xoxocotlán, Oaxaca, México \\ Corresponding Author: Marko Gómez-Hernández \\ Email address: magomezhe@conacyt.mx
}

Wild edible mushrooms have been collected and consumed by human groups for centuries, and today they represent a relevant source of food and income for many rural families worldwide. Preserving these non-timber forest products is of great interest, and there is concern about the damage caused by intensive mushroom harvesting on macromycete communities. The aim of this study was to evaluate variation in diversity and composition of macromycete species between areas regularly used for mushroom harvesting and non-harvested areas in the Mixteca region of Oaxaca, Mexico, as well as to assess the influence of microclimatic and environmental factors on this variation. We selected two harvested and two non-harvested sites within the study area. In each one, we established 10 permanent plots of $10 \mathrm{~m} \times 10 \mathrm{~m}$ where we sampled all the observed fruit bodies weekly from June to October 2017. We recorded a total of 856 individuals corresponding to 138 species, and 23 of these were identified as edible. Overall macromycete diversity, edible species diversity and composition were similar in Sites 1 (non-harvested) and 3 (harvested), and in Sites 2 (non-harvested) and 4 (harvested). Variation of diversity and species composition along the studied area was mainly related to microclimatic variables, while most environmental variables and variables related to vegetation structure similarly affected macromycete species in the four sites. Our results indicate that intensive harvesting of wild edible mushrooms is not affecting the diversity and distribution of macromycete species in our study area. Knowledge on the sustainability of mushroom harvesting practices can help improve current regulations regarding the management of these valuable non-timber forest products. 
1 Comparison of diversity and composition of macrofungal species between intensive

2 mushroom harvesting and non-harvesting areas in Oaxaca, Mexico

3 Carolina Ruiz-Almenara ${ }^{1}$, Etelvina Gándara², Marko Gómez-Hernández ${ }^{3}$

4 CIIDIR Unidad Oaxaca, Instituto Politécnico Nacional. Santa Cruz Xoxocotlán, Oaxaca,

5 Mexico. E-mail: karoruizx@gmail.com

$6{ }^{2}$ Facultad de Ciencias Biológicas. Benemérita Universidad Autónoma de Puebla, Puebla, Puebla,

7 Mexico. E-mail: etelvina.gandara@gmail.com

$8{ }^{3}$ CONACYT-CIIDIR Unidad Oaxaca, Instituto Politécnico Nacional. Santa Cruz Xoxocotlán,

9 Oaxaca, Mexico.

10 Corresponding author:

11 39arko Gómez-Hernández

12 E-mail address: mrk.gmz@gmail.com 
20

21

22

23

24

\section{Abstract}

Wild edible mushrooms have been collected and consumed by human groups for centuries, and today they represent a relevant source of food and income for many rural families worldwide. Preserving these non-timber forest products is of great interest, and there is concern about the damage caused by intensive mushroom harvesting on macromycete communities. The aim of this study was to evaluate variation in diversity and composition of macromycete species between areas regularly used for mushroom harvesting and non-harvested areas in the Mixteca region of Oaxaca, Mexico, as well as to assess the influence of microclimatic and environmental factors on this variation. We selected two harvested and two non-harvested sites within the study area. In each one, we established 10 permanent plots of $10 \mathrm{~m}$ x $10 \mathrm{~m}$ where we sampled all the observed fruit bodies weekly from June to October 2017. We recorded a total of 856 individuals corresponding to 138 species, and 23 of these were identified as edible. Overall macromycete diversity, edible species diversity and composition were similar in Sites 1(non-harvested) and 3 (harvested), and in Sites 2 (non-harvested) and 4 (harvested). Variation of diversity and species composition along the studied area was mainly related to microclimatic variables, while most environmental variables and variables related to vegetation structure similarly affected macromycete species in the four sites. Our results indicate that intensive harvesting of wild edible mushrooms is not affecting the diversity and distribution of macromycete species in our study area. Knowledge on the sustainability of mushroom harvesting practices can help improve current regulations regarding the management of these valuable non-timber forest products. 


\section{Introduction}

43 Fungi are of great importance in forest ecosystems worldwide. As decomposers, they are the 44 most important organisms for the degradation of organic matter, and play a key role in nutrient cycling (Lodge 1993; Deacon 2006). Mycorrhizal fungi form symbiotic associations with higher plants, facilitating plant uptake of water and nutrients such as phosphorus and nitrogen, in

47 exchange for photosynthetically fixed carbon (Hall, Yun \& Amicucci 2003; Egli 2011). Plant and animal pathogenic fungi impact ecosystems mainly by acting as natural population regulators, thereby influencing productivity and species diversity and composition (Hansen \& Stone 2005; Deacon 2006).

51 In addition to their roles in ecosystem functioning, fungi are highly relevant for humans and

52 human-related activities (Mueller, Bills \& Foster 2004). Wild edible mushrooms have been

53 collected and consumed by people for thousands of years and, given their nutritional value, some 54 species are used as substitutes of meat in developing countries (Boa 2004). Wild edible macromycetes are also among the most important non-timber forest products sold worldwide, generating ca. US\$2 billion each year (Boa 2004; Voces, Diaz-Balteiro \& Alfranca 2012). Information compiled from 10 countries revealed 2166 known species of wild edible mushrooms, but they are known sources of food and income in more than 80 countries (Boa 2004).

In Mexico, at least 371 macromycete species are traditionally consumed, making it the second country with the most species of wild mushrooms used as food, only after China (600 species), and it is the sixth country in the world with the highest number of ethnic groups (Ruan-Soto,

63 Garibay-Orijel \& Cifuentes 2006; Garibay-Orijel \& Ruan-Soto 2014). The state of Oaxaca is one 64 of the most biodiverse regions in the planet, and the most biologically and culturally diverse 
65 region in Mexico (Flores-Villela \& Gerez 1994), but there is a lack of mycological information

66 for this area (Garibay-Orijel et al. 2006). The few studies on macromycetes in Oaxaca have

67 focused on the functional diversity of macrofungal communities in the Costa region (Caiafa et al.

68 2017), taxonomy and traditional use of Psilocybe species in different localities of the state

69 (Guzmán et al. 2004; Ramírez-Cruz, Guzmán \& Ramírez-Guillen 2006), the traditional use of

70 macrofungi in the Mixteca region (Santiago et al. 2016), and the diversity and traditional use of

71 macromycetes in the Sierra Norte region, which has the most complete inventory of useful

72 macromycetes in Mexico, comprising a total of 159 taxa (Garibay-Orijel et al. 2009).

73 Nevertheless, it is common knowledge that many communities throughout other regions of

74 Oaxaca also use wild mushrooms.

75 However, it has been suggested that mushroom harvesting may affect macromycete communities

76 and fruit body production in subsequent years by lowering spore-release, damaging mycelia, and

77 disrupting biotic interactions with other species (Arnolds 1995; Leonard 1997; Money 2005).

78 Due to the role of macromycetes in ecosystem processes, and their nutritional and economic

79 importance, concern about the negative effects of harvesting has grown among mycologists,

80 conservation agencies, forest managers, landowners, and mushroom traders (Boa 2004; Leonard

81 1997; Pilz et al. 2007; Pilz \& Molina 2002) Nevertheless, results from experimental and long-

82 term research have indicated that over-harvesting causes no damage to the macromycete

83 communities since only the fruit bodies are removed and the mycelium is left untouched (Norvell

84 1995; Egli et al 2006). Yet, soil compaction associated with mushroom collecting can reduce the

85 number of fruit bodies per year (Egli, Ayer \& Chatelain 1990, Egli et al 2006).

86 Therefore, researchers have recommended that collection of wild edible mushrooms should be

87 regulated, and that rare/endangered species must be identified and protected from harvesting 
88 (Leonard 1997; Money 2005). In Mexico, the lack of official statistics and scientific knowledge

89 on mushroom harvesting has caused the regulatory framework to be ambiguous, inconsistent,

90 and difficult to comply with. The Wildlife Act, for example, considers the use of wild

91 macromycetes, but if supported by a management plan with evidence showing that the extraction

92 rate does not exceed the rate of natural regeneration, making it virtually impossible to obtain an

93 official harvesting permit (Benítez-Badillo et al. 2013). Many rural communities of Oaxaca have

94 community-based systems to decide upon and regulate forest management in their territories.

95 Nevertheless, wild mushroom harvesting is frequently excluded from management plans due to

96 the scarce information about the implications of this activity.

97 The present study was carried out in a community located in the highlands of the Mixteca region

98 of Oaxaca, where people have been intensively harvesting wild edible macromycetes in the same

99 places for many years. In spite of evidence from other regions of the world showing that over-

100 harvesting causes no damage to macromycete communities, there is a widespread perception in

101 Mexico that harvesting the same area for many years diminishes the number of species and fruit

102 body production. These ideas, together with the lack of scientific information and the

103 inconsistent regulatory framework regarding wild edible mushrooms, highlight the need for

104 studies on how mushroom harvesting in different regions and ecosystems of this country may be

105 affecting the structure of macromycete communities. The aim of this study was to assess

106 differences on diversity and distribution of macromycete species between areas used for

107 mushrooms harvesting and non-harvested areas, to infer about the potential effects of collection

108 on macrofungal communities in the Mixteca region of Oaxaca. Since macromycete communities

109 are susceptible to mycelium damage, reduction of spore release, and

110 microclimatic/environmental variation, we predicted that the turnover of species composition 
111 between harvested and non-harvested sites would be conspicuous, and the likely changes of

112 diversity and distribution of macromycetes along the study area would be more related to the

113 variation of microclimatic/environmental factors than to the effect of harvesting.

115 Materials \& Methods

116 Study area and sites

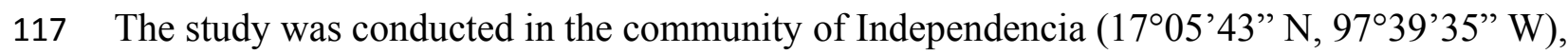

118 which is part of the municipality of San Esteban Atatlahuca, in the Mixteca region of Oaxaca,

119 Mexico. Independencia is found in the Sierra Madre del Sur mountain range at 2670 m.a.s.1., in

120 an area characterized by Oak-Pine forests. The climate is temperate subhumid with rains in the

121 summer. Temperature ranges from 10 to $16^{\circ} \mathrm{C}$, and annual precipitation from 800 to $1500 \mathrm{~mm}$

122 (INEGI 2008).

123 With the assistance of local mushroom collectors, four study sites were defined in the communal

124 forests of Independencia: two sites in areas where local residents harvest wild edible mushrooms,

125 and two areas where no harvesting takes place. Sites 1 and 2 were established in non-harvested

126 areas, and Sites 3 and 4 have been intensively harvested (all the fruit bodies in these areas were

127 collected every 2 days during 7 months each year) for the past 9 and 5 years, respectively. We

128 chose sites that were similar in their altitude (ranging from 2560 to 2700 m.a.s.1.), tree

129 composition (dominated by one unidentified species of Pinus and two unidentified species of

130 Quercus), topography of the terrain (hills with homogeneous surfaces lacking notable

131 depressions or conspicuous areas of exposed rocks), and understory coverage (present and

132 homogeneous along the study area). We tried to ensure environmental similarity between sites to 
133 avoid great differences that could mask the effects of harvesting on the variables we used to

134 explain diversity and distribution variation. In each site we established 10 permanent plots of 10

$135 \mathrm{~m} \times 10 \mathrm{~m}$ located at least $10 \mathrm{~m}$ apart from each other, totaling a sampling area of 0.1 ha per site.

\section{Explanatory variables}

137 Every sampling date we recorded the following microclimatic variables in each plot: air and soil 138 temperature $\left({ }^{\circ} \mathrm{C}\right)$, relative air humidity $(\%)$, water content in soil $(\%)$, and soil $\mathrm{pH}$. Soil 139 compaction was determined by calculating bulk density $\left(\mathrm{gm} / \mathrm{cm}^{3}\right)$ and soil porosity $(\%)$. Since 140 soil bulk density in the study sites ranged from 0.38 to $0.44 \mathrm{gm} / \mathrm{cm}^{3}$, the soil texture for all sites

141 was classified as sandy clay loam to clay loam. Other environmental variables recorded per plot 142 included: slope $\left({ }^{\circ}\right)$, aspect $\left({ }^{\circ}\right)$, canopy openness $(\%)$, and moss, rockiness and bare soil cover $143(\%)$. Leaf litter depth was measured at the beginning, middle, and the end of the sampling 144 season. In each plot we counted and measured the diameter and height of all trees with a 145 diameter $\geq 10 \mathrm{~cm}$ at $1.3 \mathrm{~m}$ above ground. Vegetation structure was characterized using the basal 146 area $\left(\mathrm{m}^{2} \mathrm{ha}^{-1}\right)$, density (individuals $\left.\mathrm{ha}^{-1}\right)$, and mean and maximum height $(\mathrm{m})$ of the trees 147 counted.

\section{Macromycete sampling}

149 It was not possible to use molecular analyses to determine the number of species in our study 150 area due to the lack of funding and limited access to suitable labs. For this reasons, we based 151 species identification on the macro and micromorphological characters of fruit bodies. Prior to

152 the sampling season, we obtained permission from the municipal authorities of San Esteban 153 Atatlahuca to collect macromycetes in our study sites. Since mushrooms are ephemeral, 154 samplings consisted in continuously collecting macromycete fruit bodies in the four sites every 
155 week. Macromycetes were collected only during the rainy season (June-October) of 2017, and

156 the sampling procedure was the same for the four study sites in order to obtain comparable data

157 useful to analyze how diversity varied along the studied area. Each site was sampled by the same

158 person every week for five months, involving the same sampling effort (i. e. number of plots per

159 site and sampling dates) in each place. To minimize the potential effect of collecting on future

160 fruit body production, only 1 or 2 fruit bodies were collected per species for identification when

161 necessary. Fruit bodies of the same species within a diameter $<50 \mathrm{~cm}$ were recorded as a single

162 individual. To avoid soil compaction and raking leaf litter, samplings and data recording within

163 the plots were carefully carried out by a single person. When specimens could not be identified

164 at the species level, they were classified as morphospecies using a higher taxonomic level

165 approach. Species were classified as edible or not based on information from local residents and

166 a literature review (Garibay-Orijel et al. 2009; Karun \& Sridhar 2017).

\section{Data analysis}

168 We recorded the number of macrofungal species in each site, and the observed species richness

169 was compared between sites by means of rarefaction curves standardizing the samples to the

170 minimum number of individuals recorded in one site. We constructed species accumulation

171 curves to determine the effectiveness of the sampling effort (i.e. number of plots). We used

172 analyses of variance (ANOVA) to determine differences between sites with regard to the number

173 of individuals for each species, the number of species per site, and soil compaction. We used

174 Tukey's HSD tests to identify pairs of means that differed from each other. Macrofungal

175 diversity was calculated with the Shannon index, and with the true diversity index of first order

176 (qD) using the multiplicative diversity decompositions of the effective numbers of species (Jost

177 2006, 2007). A single linkage hierarchical cluster analysis was performed based on composition 
178 and abundance of species. These analyses were conducted in R version 3.4.2 (R Core Team

179 2017). The completeness of the macromycete inventories was estimated using the species

180 richness estimator Jacknife 2, and the turnover of species composition was assessed with the

181 Chao-Jaccard similarity index, both of which were calculated in EstimateS 9.1.0 (Colwell 2013).

182 The Spearman correlation coefficient was calculated to determine the relationship between the

183 explanatory variables and macrofungal richness. To understand the distribution of macromycete

184 species with respect to our set of environmental, microclimatic, and vegetation structure

185 variables, we used canonical correlation analyses (CCA). A lineal regression analysis was carried

186 out to determine the relation between species similarity and geographic distance between sites.

187 The $t$-test proposed by Hutchenson (Zar 2009) was used to determine differences in Shannon

188 diversity values between sites. Unless stated otherwise, statistical analyses were performed in R

189 version 3.4.2. (R Core Team 2017).

190

191 Results

192 Macromycete species richness and taxonomic groups

193 We recorded a total of 856 individuals corresponding to 138 species, and 23 of these were

194 identified as edible species. The phylum Basidiomycota was represented by 10 orders, 33

195 families, 59 genera, and 134 species; Ascomycota was represented by 4 orders, 4 families, 4

196 genera, and 4 species (Appendix A). Site 4 had the highest macromycete species richness (72),

197 while Site 1 showed the lowest number of species (34). Similarly, the highest richness of edible

198 species was found in Site 4 (14), and the lowest in Site 1 (9) (Table 1). 
199 Similarly, the number of species estimated with the rarefaction curves (using a standardized

200 abundance of 115 individuals) indicated that Sites 2 and 4 had the highest richness (42 and 38

201 species, respectively) compared to Sites 1 and 3 (33 and 35 species, respectively) (Figure 1A).

202 The rarefaction and species accumulation curves did not reach the asymptote, suggesting that our

203 species inventories were not complete (Figures 1 A, B), however, the richness estimator Jacknife

2042 indicated that the inventories were more than 50\% complete. Variation of the estimated

205 richness among sites corresponded to the variation of the recorded number of species (Table 1).

206 The ANOVA for the abundance of each species indicated no differences between sites $(p=$

207 0.87), as well as the Tukey's HSD. The ANOVA for the number of species, did indicate

208 differences in species richness between sites $(p=0.009)$, but the Tuke's HSD test revealed that

209 only Sites 1 and 4 differed significantly $(p=0.017)$.

\section{Macromycete diversity and distribution}

212

213

214

215

216

217

218

219

220
Both the Shannon and true diversity indices (Table 1) indicated that Site 2 had the highest diversity of macromycetes (1.54 and 35, respectively), and Site 1 had the lowest (1.17 and 14.83, respectively). The same patterns of Shannon and true diversity were observed for the edible species (Table 1), with Site 2 being the most diverse (0.96 and 9.08, respectively), and Site 1 being the least diverse ( 0.57 and 3.7 , respectively). We found no statistical differences in Shannon diversity between Sites 1 (non-harvested area) and 3 (harvested area), and between Sites 2 (non-harvested area) and 4 (harvested area). The proportion of edible species with respect to the total of species recorded in each site was $26.5 \%$ for Site $1,18.8 \%$ for Site $2,20.8 \%$ for Site 3 , and $19.4 \%$ for Site 4 .

Peer) reviewing PDF | (2019:05:37699:2:0:NEW 13 Nov 2019) 
221 The microclimatic variables showed that air and soil temperature were higher in Sites 1 and 3,

222 while relative air humidity was higher in Sites 2 and 4, and water content in soil was higher in

223 Site 2 (Figure 2). Spearman's correlation coefficient indicated that macromycete richness was

224 positively correlated with relative air humidity, herbaceous plant coverage, slope, maximum tree

225 height and tree basal area; and negatively correlated with air and soil temperature (Table 2).

226 The cluster analysis indicated that Sites 1 and 3 were similar in species composition, and Site 2

227 was similar to Site 4 (Figure 3). Correspondingly, the Chao-Jaccard showed that for both the

228 total macromycete species and the edible species, Sites 1 (non-harvested area) and 3 (harvested

229 area) were the most similar, followed by Sites 2 (non-harvested area) and 4 (harvested area).

230 Sites 1 and 4 were the most dissimilar in terms of total macromycete species, and Sites 1 and 2

231 were the most different with respect to edible species (Table 3). Geographic distance between

232 sites and values of the Chao-Jaccard index were not significantly related $(p=0.6)$.

233 The CCA with microclimatic explanatory variables was carried out for 138 macromycete species

234 considering air temperature, relative air humidity, soil temperature and percentage of water in the

235 soil. The model only retained air and soil temperature, but the other variables were included to

236 better explain the ordination. Axis $1($ eigenvalue $=0.4926)$ and axis $2($ eigenvalue $=0.3226)$

237 accounted for $37 \%$ and $24 \%$ of the species-microclimate relationship, respectively. CCA results

238 showed that Sites 1 and 3 were clearly separated from Sites 2 and 4 along the first canonical axis

239 (Figure 4).

240 The CCA for environmental variables was also carried out for the 138 macromycete species

241 considering litterfall, canopy openness, slope, aspect, rockiness, moss and herbaceous coverage,

242 bulk density, soil porosity and water-filled soil pore space. The model only retained moss

243 coverage, but the other variables contributed to explain the ordination. Axis 1 (eigenvalue $=$ 
2440.4213 ) and axis 2 (eigenvalue $=0.3545$ ) accounted for $17 \%$ and $14 \%$ of the explained species-

245 environmental relationship, respectively (Figure 5).

246 The CCA for vegetation structure also considered 138 species and used mean tree height,

247 maximum tree height, tree basal area and tree density. The model only retained maximum tree

248 height, but the other variables were included to explain the ordination. Axis 1 (eigenvalue $=$

$2490.4509)$ and axis 2 (eigenvalue $=0.3049$ ) accounted for $38 \%$ and $25 \%$ of the explained species-

250 vegetation structure relationship, respectively. CCA results showed that Sites 1 and 3 were

251 separated from Sites 2 and 4 along the first canonical axis (Figure 6).

Discussion

254

255

256

257

258

259

260

261

262

263

264

265

Mexico is one of the main consumers of wild edible mushrooms in the world. Different studies have shown the high diversity of these organisms in the country and their importance as sources of food and income for human communities in rural areas. For instance, in a forest of La Malinche National Park in Tlaxcala, 93 macrofungal species were recorded, 91 of them reported in the literature as edible, and 74 species were found to be used by the local people (Montoya et al. 2004). In Ixtlan, Oaxaca, 159 macromycete taxa were reported as having a use, including 113 edible species (Garibay-Orijel et al. 2009). In the Sierra del Ajusco, in Mexico City, 29 wild edible species were found in just 800 m2 (Zamora-Martinez \& Nieto de Pascual-Pola 1994). In Cerro El Zamora, located between Guanajuato and Queretaro, a study identified 130 macromycete species, 55 of which were recognized as edible based on a literature review (Landeros et al. 2006). In our study area, a total of 138 macromycete taxa were recorded, and 23 were recognized as edible according to a literature review. Interviews with local people, 
266 performed as part of an ethnomycological study conducted simultaneously to this one, showed

267 that they consume at least 45 species. Despite the fact that most studies on macromycetes

268 comprise 1 to 3 years of sampling, it has been suggested that 5 to 10 years would be more

269 suitable (O’Dell et al. 2004), but it is rarely possible to sample over the many years required to

270 document most of the species (Gabel \& Gabel 2007). Our sampling period spanned only one

271 year, however, the aim of this study was not to obtain complete macromycete inventories but to

272 assess the diversity variation among harvested and non-harvested areas, so we used the same

273 systematized procedure in the four study sites (see Methods) to get comparable data. Although

274 our permanent plots in the harvesting sites were marked with barricade tape and it was agreed

275 with the local population that they would not collect mushrooms within the plots during the

276 sampling season, traces of harvesting were often found. Locals ensure that they only collected

277 Tricholoma mesoamericanum in our plots, which could explain why the species was not

278 recorded by us.

279 The diversity of macromycetes did not differ between the non-harvested (Sites 1 and 2) and

280 harvested (Sites 3 and 4) areas. Both for all macrofungi and for the edible species, Sites 2 and 4

281 showed a similar diversity and were the most diverse, while Sites 1 and 3 were similar and less

282 diverse. It is broadly known that macromycete communities are strongly influenced by habitat

283 heterogeneity and microclimatic variation, and our results on diversity can be clearly explained

284 by the observed microclimatic conditions. In spite of having similar environmental conditions

285 and vegetation structure in the four studied sites, microclimate was not homogeneous throughout

286 and the differences corresponded to the observed patterns of diversity where Sites 2 and 4 on the

287 one hand, and Sites 1 and 3 on the other, were more similar to each other in terms of the

288 microclimate and macromycete diversity. Several studies have suggested that humidity, 
289 precipitation and temperature are the main factors affecting macromycete fruiting and diversity 290 in both temperate and tropical forests (e. g. O’Dell, Ammirati \& Schreiner 2000; Ohenoja 1995;

291 Lodge et al. 2004; Brown, Bhagwat \& Watkinson 2006; Durall et al. 2006; Gomez et al. 2012), 292 and that temperature and humidity are the best predictors for fungal richness (Talley, Coley \& 293 Kursar 2002). Our results showed that air and soil temperatures were higher in Sites 1 and 3, and 294 negatively correlated with macromycete species richness. Likewise, air humidity was higher in 295 Sites 2 and 4, and positively correlated with species richness. These results suggest that mushroom harvesting is not likely affecting the assemblages of edible macromycetes, nor disturbing environmental factors of relevance for macrofungal communities. This is consistent with different long term studies evaluating the effect of mushroom harvesting on the number of macromycete species and fruit body production. In a 29-year study carried out within two fungus reserves in southwestern Switzerland, systematic harvesting was applied using picking and cutting techniques and the results indicated that regardless of the harvesting technique, neither macromycete species richness nor fruiting were affected (Egli et al. 2006). Similarly, 13- and 40year studies conducted in the United States and Sweden, respectively, revealed that intensive collecting of wild mushrooms did not reduce annual production of fruit bodies (Jahn \& Jahn 1986; Norvell 1995). It has been suggested that stability in the number of macromycete species and fruiting in areas under harvesting pressure may be explained by the hundreds of spores released from each fruit body before and during mushroom collection, or because enough spores disperse from adjacent areas (Money 2005; Egli et al. 2006). macrofungal diversity and fruit body production, such as slope, aspect, basal area, presence of 311 rocks, and density of trees (O’Dell, Ammirati \& Schreiner 2000; Ferris, Peace \& Newton 2000; 
312 Cavender-Bares et al. 2009; Egli et al. 2010; Gomez et al. 2012). Our results showed a positive

313 correlation between slope and the number of macromycete species, agreeing with findings by

314 Caiafa et al. (2017) in the Costa region of Oaxaca. But understanding how the slope influences

315 macromycete richness can be a difficult task due to the variety of biotic and abiotic factors

316 related to the soil environment. Findings have suggested that the slope effect on macromycetes is

317 related to vegetation type, as well as to the moisture and temperature gradient along the slope.

318 However, there are discrepancies between studies since some of them report a positive relation

319 between slope and species richness, and others repot it to be negative (Nantel \& Neumann 1992;

320 Rubino \& McCarthy 2003; Gómez-Hernández et al. 2012). In this study, basal area and

321 maximum height of trees were positively correlated with species richness, and a greater amount

322 of fruit bodies were recorded in areas with wider and taller trees. Correspondingly, the highest

323 basal area, maximum height of trees, and macromycete richness and abundance were recorded in

324 Site 4. Related studies have proposed that the composition and structure of host tree communities

325 can influence macromycete richness and fruit body production by affecting fungal specialization

326 and providing different habitats and resource quality and quantities (Villeneuve, Grandtner \&

327 Fortin 1989; Richard et al. 2004; Brown, Bhagwat \& Watkinson 2006; Zhang et al. 2010). In our

328 study, herbaceous cover was positively correlated with macromycete species richness, agreeing

329 with results that suggest a trend towards increasing the number of macromycete fruit bodies with

330 increased presence of herbaceous plants, and a positive relation between the number of

331 macromycete species and fruit body production (Mehus 1986; Toledo, Barroetaveña \&

332 Rajchenberg 2014). The observed trend can be explained by the fact that the herbaceous layer

333 provides up to $16 \%$ of annual litter fall and influences the cycling rates of $\mathrm{N}, \mathrm{P}, \mathrm{K}$ and $\mathrm{Mg}$, which

334 are important nutrients for fungal growth and health (Gilliam 2007). Soil compaction by 
335 trampling has been proposed as one of the consequences from harvesting that can trigger a

336 decrease in macromycete diversity and fruit body production by causing mycelium smashing

337 (Arnolds 1995; Watling 2003). Egli, Ayer \& Chatelain (1990) intensively trampled a plot every 2

338 days during summer and autumn for 1 year, and observed a strong decrease in fruit body

339 production. People in our study area harvest mushrooms every 2 days for 7 months every year,

340 however, the soil water content (which is directly related to soil compaction) was similar

341 between non-harvested and harvested sites, and macromycete abundance was higher in the

342 harvesting sites. Also, the ANOVA for soil compaction showed no differences between sites.

343 These results suggest that trampling due to mushroom collection has not caused severe soil

344 compaction and damage to the macofungal communities despite many years of intensive

345 harvesting.

346 The sites assessed are covered by pine-oak forests with marked dominance of pines, and the

347 composition of tree species was similar in all sites. In forests with low diversity of tree species,

348 as in our study, the opportunity for macromycete specialization increases due to the high

349 abundance of few tree species, and the composition of specialist fungi has been observed to

350 change across the distribution of a vegetation type (Nantel \& Neumann 1992; Ferrer \& Gilbert

351 2003; Lodge et al. 2008). The turnover of macromycete species between our four study sites was

352 not as conspicuous as expected. The similarity in species composition ranged from 55 to $79 \%$,

353 and resembled the trend observed for microclimate since it was similar between Sites 2 (non-

354 harvested) and 4 (harvested), and between Sites 1 (non-harvested) and 3 (harvested).

355 Corresponding with our results, other studies have reported that variation of macrofungal species

356 composition between sites, within a same vegetation type, was more related to precipitation and

357 temperature than to the composition of tree assemblages (Marmolejo \& Méndez-Cortes 2007; 
358 Cavender-Bares et al. 2009; Gómez \& Williams-Linera 2011). Furthermore, the ordination

359 analyses indicated that air and soil temperature, relative air humidity, and the humidity-related

360 variables of moss coverage and maximum tree height were the main factors involved in the

361 distribution of macromycetes throughout our studied area. Other environmental and vegetation

362 structure variables were homogeneous in the four studied sites and equally related to

363 macromycete distribution, thus they did not play a key role in the observed changes in species

364 composition between study sites. In accordance with our results on diversity and species

365 richness, our findings suggest that microclimatic differences best explained the differences in

366 macromycete distribution along the studied area.

367 In order to avoid pseudoreplication issues, we had ten plots (subsamples) in each study site

368 (replicates) for data collection, and these were analyzed as independent samples. Nevertheless, it

369 was only possible to establish four sites in the study area, thus two replicates were assigned to

370 each treatment (i. e. harvested and non-harvested). In spite of having more than one

371 observational unit for each treatment, the low number of replicates could result in an

372 underestimation of the variability in the treatments. Our results correspond to others reported in

373 several previously mentioned studies, but it would have been valuable to include a larger number

374 of study sites in each treatment to make our results more robust.

376 Conclusions

377 This study has shown that harvesting wild edible mushrooms for several years within a specific

378 area may not represent a threat to macrofungal communities, and it can be a sustainable activity.

379 Patterns of diversity and distribution of macromycetes along harvested/non-harvested areas are 
380 mainly determined by the intrinsic microclimatic variation between sites. The present study

381 included only one season of data, which could be a limitation to capture long-term differences.

382 Thus carrying out long term studies on different ecosystems and evaluating harvesting

383 techniques is of great interest to elucidate the most suitable methods to best manage this valuable

384 non-timber forest product. Surveys along disturbance gradients are also desirable to clearly

385 determine whether harvesting wild mushrooms is an innocuous activity as long as the general

386 environment and macromycete habitat are not disturbed. Generating more information on this

387 activity will allow improving regulatory frameworks and not to exclude mushroom harvesting

388 from management and conservation plans.

\section{Aknowledgments}

391 We thank Dr. Virginia Ramírez Cruz and M. Sc. Alonzo Cortés Pérez for their help with

392

393

394

395

396

397

398

399 macromycete identification in the field and herbarium; Dra. Sandra Smith Aguilar for helpful suggestions and comments on earlier versions of this manuscript; Raúl Rivera García for his help with the figures edition. This research was partially supported by CONACyT through the studentship (No. 611195) granted to the first author. 
400 Arnolds, E. (1995). Conservation and management of natural populations of edible fungi.

401 Canadian Journal of Botany. https://doi.org/10.1139/b95-349

402 Benítez-Badillo, G., Alvarado-Castillo, G., Nava-Tablada, M., and Pérez-Vázquez, A. (2013).

403 Análisis del marco regulatorio en el aprovechamiento de los hongos silvestres comestibles en

404 México. Revista Chapingo. Serie Ciencias Forestales y del Ambiente.

405 Boa, E. (2004). Wild edible fungi: A global overview of their use and importance to people.

406 Non-wood Forest Products. https://doi.org/10.1007/978-3-319-13865-7

407 Brown, N., Bhagwat, S., and Watkinson, S. (2006). Macrofungal diversity in fragmented and

408 disturbed forests of the Western Ghats of India. Journal of Applied Ecology.

409 https://doi.org/10.1111/j.1365-2664.2005.01107.x

410 Caiafa, M. V., Gómez-Hernández, M., Williams-Linera, G., and Ramírez-Cruz, V. (2017).

411 Functional diversity of macromycete communities along an environmental gradient in a Mexican

412 seasonally dry tropical forest. Fungal Ecology. https://doi.org/10.1016/j.funeco.2017.04.005

413 Cavender-Bares, J., Izzo, A., Robinson, R., and Lovelock, C. E. (2009). Changes in

414 ectomycorrhizal community structure on two containerized oak hosts across an experimental

415 hydrologic gradient. Mycorrhiza. https://doi.org/10.1007/s00572-008-0220-3

416 Colwell, R. K. (2013). EstimateS, Version 9.1: Statistical Estimation of Species Richness and 417 Shared Species from Samples. http://viceroy.eeb.uconn.edu/estimates/

418 Deacon, J. (2006). Fungal Biology. Malden, MA USA: Blackwell Publishing Ltd. (Chapter 1).

419 https://doi.org/10.1002/9781118685068 
420 Durall, D. M., Gamiet, S., Simard, S. W., Kudrna, L., and Sakakibara, S. M. (2006). Effects of

421 clearcut logging and tree species composition on the diversity and community composition of

422 epigeous fruit bodies formed by ectomycorrhizal fungi. Canadian Journal of Botany.

423 https://doi.org/10.1139/b06-045

424 Egli, S. (2011). Micorrhizal mushroom diversity and productivity- an indicator of forest healt?

425 Annals of Forest Science. https://doi.org/10.1007/s13595-010-0009-3

426 Egli, S., Ayer, F., Peter, M., Eilmann, B., and Rigling, A. (2010). Is forest mushroom

427 productivity driven by tree growth? Results from a thinning experiment. Annals of Forest

428 Science. https://doi.org/10.1051/forest/2010011

429 Egli, S., Peter, M., Buser, C., Stahel, W., and Ayer, F. (2006). Mushroom picking does not 430 impair future harvests - Results of a long-term study in Switzerland. Biological Conservation.

431 https://doi.org/10.1016/j.biocon.2005.10.042

432 Egli, S., Ayer, F., and Chatelain, F. (1990). Die Einfluss des Pilzsammelns auf die Pilzflora.

433 Mycologia Helvetica. 3: 4 17-428.

434 Ferrer, A., and Gilbert, G. S. (2003). Effect of tree host species on fungal community

435 composition in a tropical rain forest in Panama. Diversity and Distributions.

436 https://doi.org/10.1046/j.1472-4642.2003.00039.x

437 Ferris, R., Peace, A. J., and Newton, A. C. (2000). Macrofungal communities of lowland Scots

438 pine (Pinus sylvestris L.) and Norway spruce (Picea abies (L.) Karsten.) plantations in England: 
439 Relationships with site factors and stand structure. Forest Ecology and Management.

440 https://doi.org/10.1016/S0378-1127(99)00218-2

441 Flores-Villela, O., and Gerez, P. (1994). Biodiversidad y conservación en México: vertebrados,

442 vegetación y uso del suelo. Conabio y UNAM. https://doi.org/10.1017/CBO9781107415324.004

443 Garibay-Orijel R., and Ruan-Soto, F. (2014). Listado de los hongos silvestres comestibles como

444 alimento tradicional en México. In A. Moreno-Fuentes and R. Garibay-Orijel (Eds.), La

445 etnomicología en México, Estado del Arte (pp.91-109). Ciudad de México: Red de Etnoecología

446 y Patrimonio Biocultural (CONACyT)- Universidad Autónoma del Estado de Hidalgo-Instituto

447 de Biología (UNAM)-Sociedad Mexicana de Micología-Asociación Etnobiológica Mexicana,

448 A.C.-Grupo Interdisciplinario para el Desarrollo de la Etnomicología en México-Sociedad

449 Latinoamericana de Etnobiología.

450 Garibay-Orijel, R., Cifuentes, J., Estrada-Torres, A., and Caballero, J. (2006). People using 451 macro-fungal diversity in Oaxaca, Mexico. Fungal Diversity.

452 Garibay-Orijel, R., Córdova, J., Cifuentes, J., Valenzuela, R., Estrada-Torres, A., and Kong, A. 453 (2009). Integrating wild mushrooms use into a model of sustainable management for indigenous 454 community forests. Forest Ecology and Management.

455 https://doi.org/10.1016/j.foreco.2009.03.051

456 Gilliam, F. S. (2007). The ecological significance of the herbaceous layer in temperate forest 457 ecosystems. BioScience. https://doi.org/10.1641/B571007 
458 Gómez-Hernández, M., and Williams-Linera, G. (2011). Diversity of macromycetes determined

459 by tree species, vegetation structure, and microenvironment in tropical cloud forests in Veracruz, 460 Mexico. Botany. https://doi.org/10.1139/B11-007

461 Gómez-Hernández, M., Williams-Linera, G., Guevara, R., and Lodge, D. J. (2012). Patterns of

462 macromycete community assemblage along an elevation gradient: Options for fungal gradient 463 and metacommunity analyse. Biodiversity and Conservation. https://doi.org/10.1007/s10531$464 \quad 011-0180-3$

465 Guzmán, G., Escalona, F., Ramírez-Guillén, F., and Jacobs, J. Q. (2004). New hallucinogenic 466 mushrooms in Mexico belonging to the genus Psilocybe (Basidiomycotina, Agaricales, 467 Strophariaceae). International Journal of Medicinal Mushrooms, 6, 275-286.

468 https://doi.org/10.1615/IntJMedMushr.v6.i3.70

469 Hall, I. R., Yun, W., and Amicucci, A. (2003). Cultivation of edible ectomycorrhizal 470 mushrooms. Trends in Biotechnology. https://doi.org/10.1016/S0167-7799(03)00204-X

471 Hansen, E. M., and Stone, J. K. (2005). Interactions of pathogens with plant communities. In J.

472 Dighton, P. Oudemans, and White, J. (Eds). The Fungal Community (p. 461), Marcel Dekker, 473 New York.

474 INEGI. Instituto Nacional de Estadística y Geografía. Prontuario de información geográfica 475 municipal de los Estados Unidos Mexicanos, San Esteban Atatlahuca, Oaxaca, clave 476 geoestadística 20133. (2008).

477 http://www3.inegi.org.mx/contenidos/app/mexicocifras/datos_geograficos/20/20133.pdf/ 478 Accesed 10 November 2018 
479 Jahn, H., and Jahn, M. A. (1986). Konstanz und Fluktuation der Pilzvegetation in Norra Warleda 480 (Uppland). Beobachtungen auf einem schwedischen Bauernhof. Westfälische Pilzbriefe 10/11, $481 \quad 352-378$.

482 Jost, L. (2006). Entropy and diversity. Oikos. https://doi.org/10.1111/j.2006.0030-1299.14714.x

483 Jost, L. (2007). Partitioning diversity into independent alpha and beta components. Ecology. 484 https://doi.org/10.1890/06-1736.1

485 Karun, N. C., and Sridhar, K. R. (2017). Edible wild mushrooms of the Western Ghats: Data on 486 the ethnic knowledge. Data in Brief. https://doi.org/10.1016/j.dib.2017.07.067

487 Landeros, F., Castillo, J., Guzmán, G., and Cifuentes, J. (2006). Los hongos (macromicetos) 488 conocidos en el Cerro el Zamorano (Querétaro-Guanajuato), México. Revista Mexicana de 489 Micología.

490 Leonard, P. (1997). A scientific approach to a policy on commercial collecting of wild fungi. 491 Mycologist 11, 89-91. https://doi.org/10.1016/S0269-915X(97)80047-X

492 Lodge, D. J. (1993). Nutrient cycling by fungi in wet tropical forests. Aspects of Tropical 493 Mycology, (May), 38-57.

494 Lodge, D. J., Ammirati, J. F., O’Dell, T. E., and Mueller, G. M. (2004). Collecting and 495 Describing Macrofungi. In Mueller, G. M., Bills, G. F., and Foster, M. S. (Eds.), Biodiversity of 496 Fungi: Inventory and Monitoring Methods (pp. 128-168). Elsevier

497 Inc. https://doi.org/10.1016/j.meatsci.2010.03.020 
498 Lodge, D. J., Læssøe, T., Aime, M. C., and Henkel, T. W. (2008). Montane and cloud forest

499 specialists among neotropical Xylaria species. North American Fungi.

500 https://doi.org/10.2509/naf2008.003.00713

501 Marmolejo, J. G., and Méndez Cortes, H. (2007). Diversidad de hongos causantes de pudrición

502 de la madera en cinco especies de pinos en Nuevo León, México. Revista Mexicana de

503 Micología, 25, 51-57.

504 Mehus, H. (1986). Fruit body production of macrofungi in some North Norwegian forest types.

505 Nordic Journal of Botany. https://doi.org/10.1111/j.1756-1051.1986.tb00468.x

506 Money, N. P. (2005). Why picking wild mushrooms may be bad behavior. Mycological

507 Research. https://doi.org/10.1017/S0953756205252371

508 Montoya, A., Kong, A., Estrada-Torres, A., Cifuentes, J., and Caballero, J. (2004). Useful wild 509 fungi of La Malinche National Park, Mexico. Fungal Diversity.

510 Mueller, G. M., Bills, G. F., and Foster, M. S. (2004). Biodiversity of Fungi: Inventory and

511 Monitoring Methods. Biodiversity of Fungi: Inventory and Monitoring Methods.

512 https://doi.org/10.1016/B978-0-12-509551-8.X5000-4

513 Nantel, P., and Neumann, P. (1992). Ecology of ectomycorrhizal-basidiomycete communities on

514 a local vegetation gradient. Ecology. https://doi.org/10.1210/er.2008-0024

515 Norvell, L. (1995). Loving the chanterelle to death? The ten-year Oregon Chanterelle Project.

516 McIlvainea. 12, 6-25. 
517 O’Dell, T. E., Ammirati, J. F., and Schreiner, E. G. (2000). Species richness and abundance of

518 ectomycorrhizal basidiomycete sporocarps on a moisture gradient in the Tsuga heterophylla

519 zone. Canadian Journal of Botany. https://doi.org/10.1139/b99-144

520 Ohenoja, E. (1995). Effects of winter conditions on the fruit body production of larger fungi.

521 Acta Universitatis Upsaliensis. Symb. Bot. Ups. 30: 163-168

522 Pilz, D., and Molina, R. (2002). Commercial harvests of edible mushrooms from the forests of

523 the Pacific Northwest United States: Issues, management, and monitoring for sustainability.

524 Forest Ecology and Management 155: 3-16 https://doi.org/10.1016/S0378-1127(01)00543-6.

525 Pilz, D., McLain, R., Alexander, S., Villarreal-Ruiz, L., Berch, S., Wurtz, T. L., Parks, C. G.,

526 McFarlane, E., Baker, B., Molina, R., and Smith, J. E. (2007). Ecology and management of

527 morels harvested from the forests of western North America. Pacific Northwest Research

528 Station: Gen. Tech. Rep. PNW-GTR-710. Portland, OR: U.S. Department of Agriculture, Forest

529 Service. https://doi.org/10.2737/PNW-GTR-710

530 R Core Team, (2017). R: a Language and Environment for Statistical Computing, 3.4.2 Ed. R

531 Foundation for Statistical Computing, Vienna, Austria. https://www. R-project.org.

532 Ramírez-Cruz, V., Guzmán, G., and Ramírez-Guillén, F. (2006). Las especies del género

533 Psilocybe conocidas del Estado de Oaxaca, su distribución y relaciones étnicas. Revista

534 Mexicana de Micologia. 
535 Richard, F., Moreau, P. A., Selosse, M. A., and Gardes, M. (2004). Diversity and fruiting

536 patterns of ectomycorrhizal and saprobic fungi in an old-growth Mediterranean forest dominated

537 by Quercus ilex L. Canadian Journal of Botany. https://doi.org/10.1139/b04-128

538 Ruán-Soto, F., Garibay-Orijel, R., and Cifuentes, J. (2006). Process and dynamics of traditional

539 selling wild edible mushrooms in tropical Mexico. Journal of Ethnobiology and Ethnomedicine.

540 https://doi.org/10.1186/1746-4269-2-3

541 Rubino, D. L., and McCarthy, B. C. (2003). Composition and ecology of macrofungal and

542 myxomycete communities on oak woody debris in a mixed-oak forest of Ohio. Canadian

543 Journal of Forest Research. https://doi.org/10.1139/x03-137

544 Santiago, F. H., Moreno, J. P., Cázares, B. X., Suárez, J. J. A., Trejo, E. O., de Oca, G. M. M.,

545 and Aguilar, I. D. (2016). Traditional knowledge and use of wild mushrooms by Mixtecs or Ñuu

546 savi, the people of the rain, from Southeastern Mexico. Journal of Ethnobiology and

547 Ethnomedicine. https://doi.org/10.1186/s13002-016-0108-9

548 Talley, S. M., Coley, P. D., and Kursar, T. A. (2002). The effects of weather on fungal

549 abundance and richness among 25 communities in the Intermountain West. BMC Ecology.

550 https://doi.org/10.1186/1472-6785-2-7

551 Toledo, C. V., Barroetaveña, C., and Rajchenberg, M. (2014). Fenología y variables ambientales

552 asociadas a la fructificación de hongos silvestres comestibles de los bosques andino-patagónicos

553 en Argentina. Revista Mexicana de Biodiversidad. https://doi.org/10.7550/rmb.40010 
554 Villanueva-Jiménez, E., Villegas-Ríos, M., Cifuentes-Blanco, J., and León-Avendaño, H. (2006).

555 Diversidad del género Amanita en dos áreas con diferente condición silvícola en Ixtlán de Juárez,

556 Oaxaca, México. Revista Mexicana de Biodiversidad.

557 Villeneuve, N., Grandtner, M. M., and Fortin, J. A. (1989). Frequency and diversity of

558 ectomycorrhizal and saprophytic macrofungi in the Laurentide Mountains of Quebec. Canadian

559 Journal of Botany. https://doi.org/10.1139/b89-338

560 Voces, R., Diaz-Balteiro, L., and Alfranca, Ó. (2012). Demand for wild edible mushrooms. The 561 case of Lactarius deliciosus in Barcelona (Spain. Journal of Forest Economics.

562 http://doi.org/10.1016/j.jfe.2011.06.003

563 Watling, R. (2003) Fungi. The Natural History Museum, London.

564 Zamora-Martínez, M. C., and Nieto de Pascual-Pola, C. (1995). Natural production of wild 565 edible mushrooms in the southwestern rural territory of Mexico City, Mexico. Forest Ecology 566 and Management. https://doi.org/10.1016/0378-1127(94)03450-B

567 Zar, J. H. (2009). Biostatistical Analysis, Fifth Edition. Pearson.

568 Zhang, Y., Zhou, D. Q., Zhao, Q., Zhou, T. X., and Hyde, K. D. (2010). Diversity and ecological 569 distribution of macrofungi in the Laojun Mountain region, southwestern China. Biodiversity and 570 Conservation. https://doi.org/10.1007/s10531-010-9915-9 
Figure 1

A) Rarefaction and B) accumulation curves for species richness in the four studied sites based on a standardized number of individuals and plots as sampling effort, respectively.

Vertical dotted line in rarefaction curves indicates species richness for the minimum number of individuals recorded in a study site.
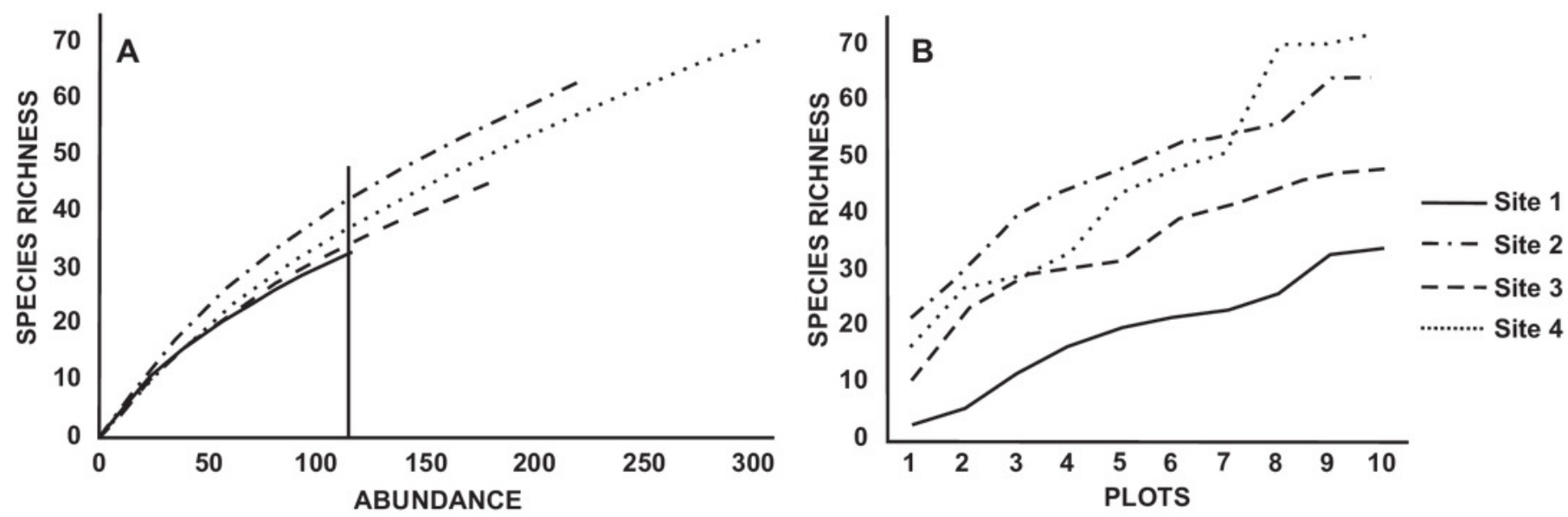
Figure 2

Monthly variation of A) soil water content, B) air temperature, C) air relative humidity, and $D$ ) soil temperature in the studied sites through the sampling season.
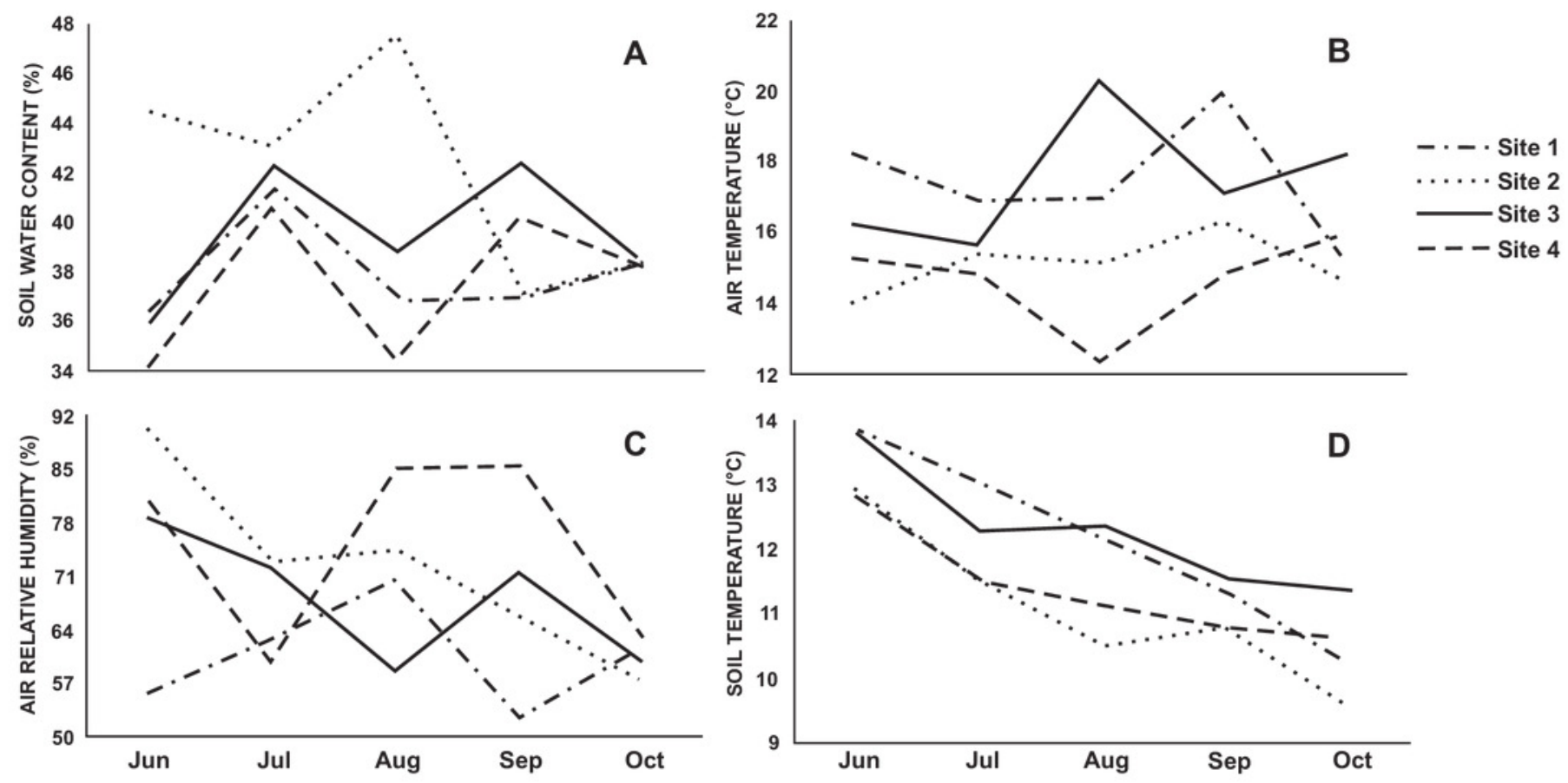
Figure 3

Cluster analysis for the four studied sites, based on composition of species and abundance.

Euclidian distance is indicated by height values.

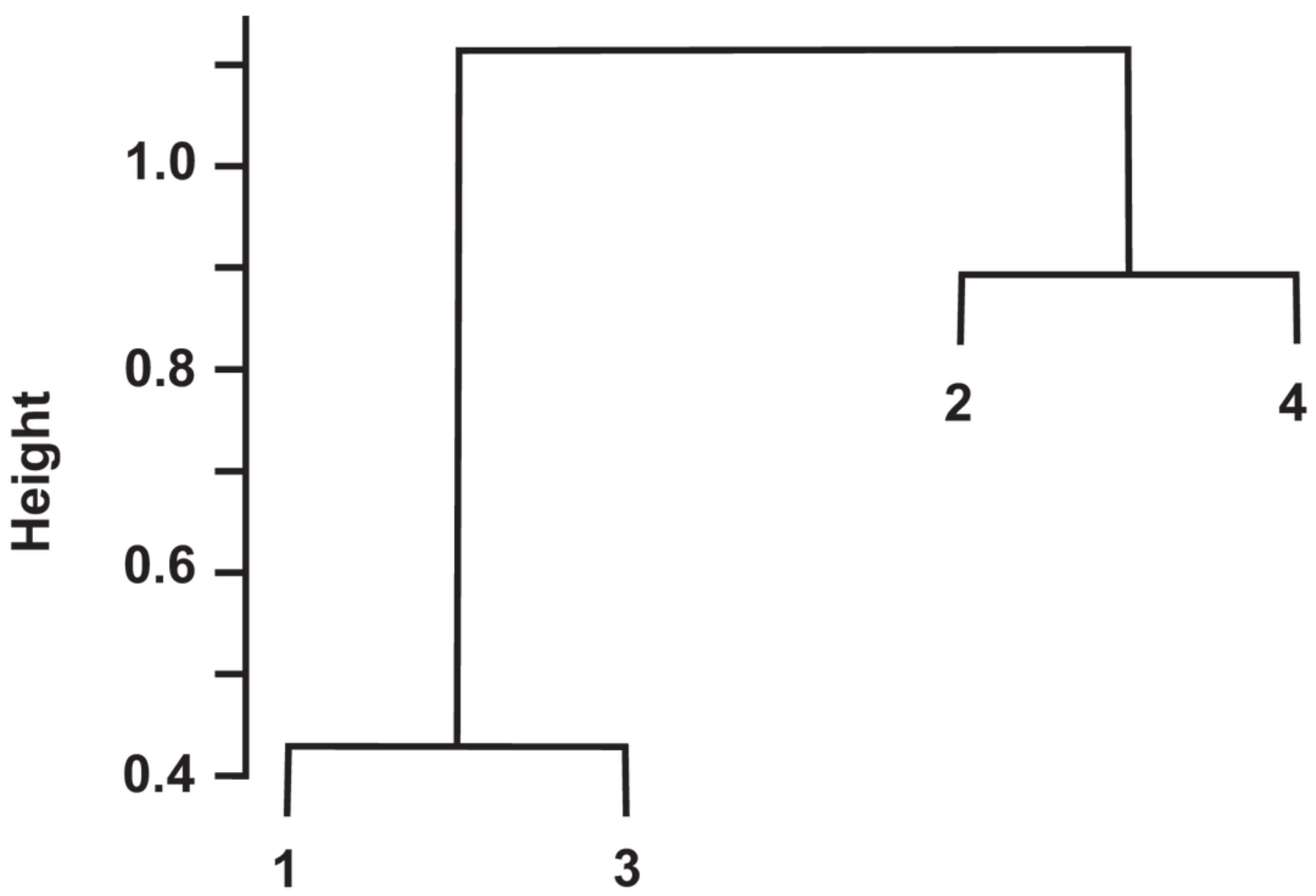


Figure 4

CCA for all the recorded macromycetes in the four study sites.

Vectors are microclimatic explanatory variables: soil temperature (soilT), soil water content (soilW), air relative humidity (airH), and air temperature (airT). 


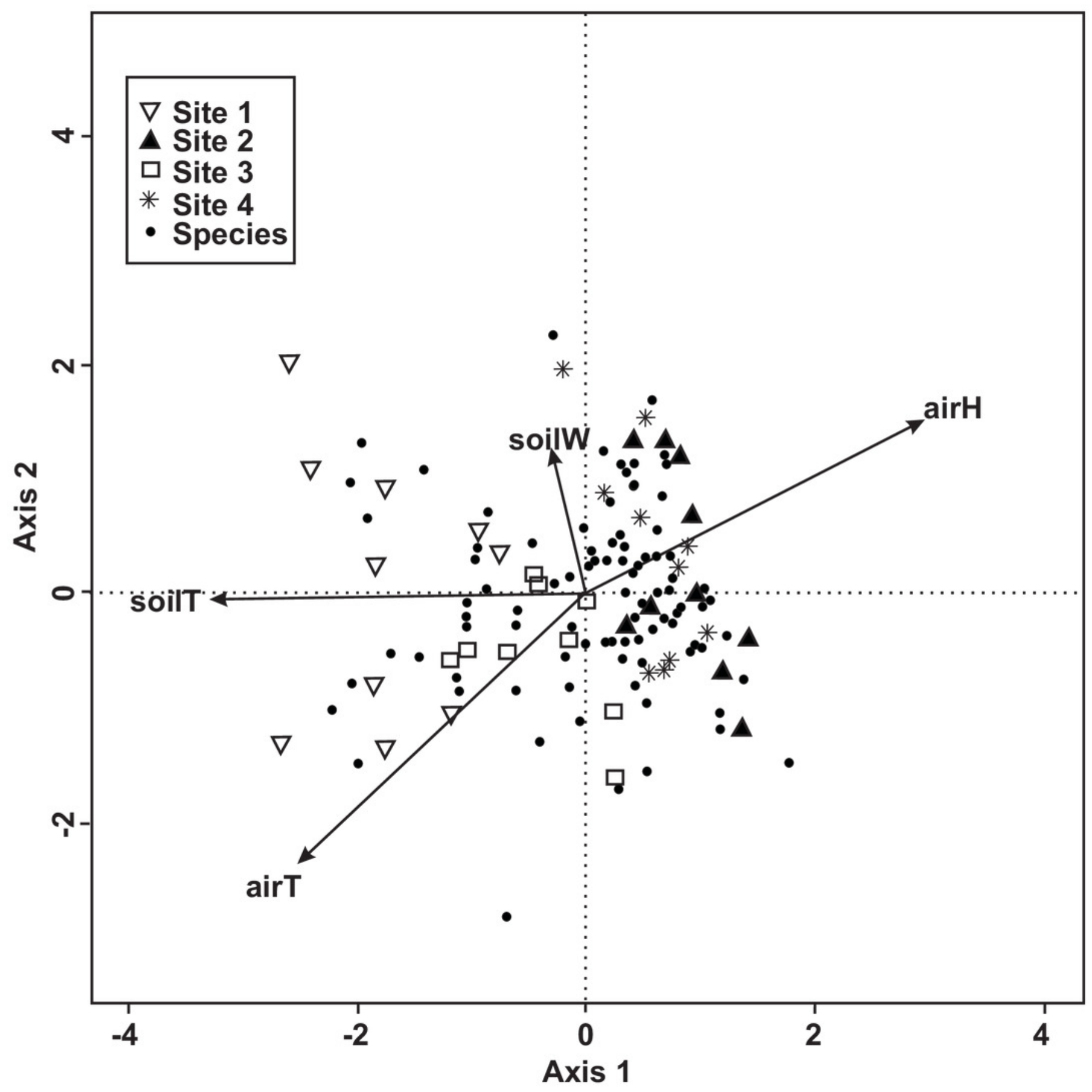


Figure 5

CCA for all the recorded macromycetes in the four study sites.

Vectors are environmental explanatory variables: bulk density (bulkD), herbaceous coverage (herbs), rockiness coverage (rock), slope, canopy, moss coverage (moss), litterfall, aspect, and soil pore space filled with water (waterFPS). 


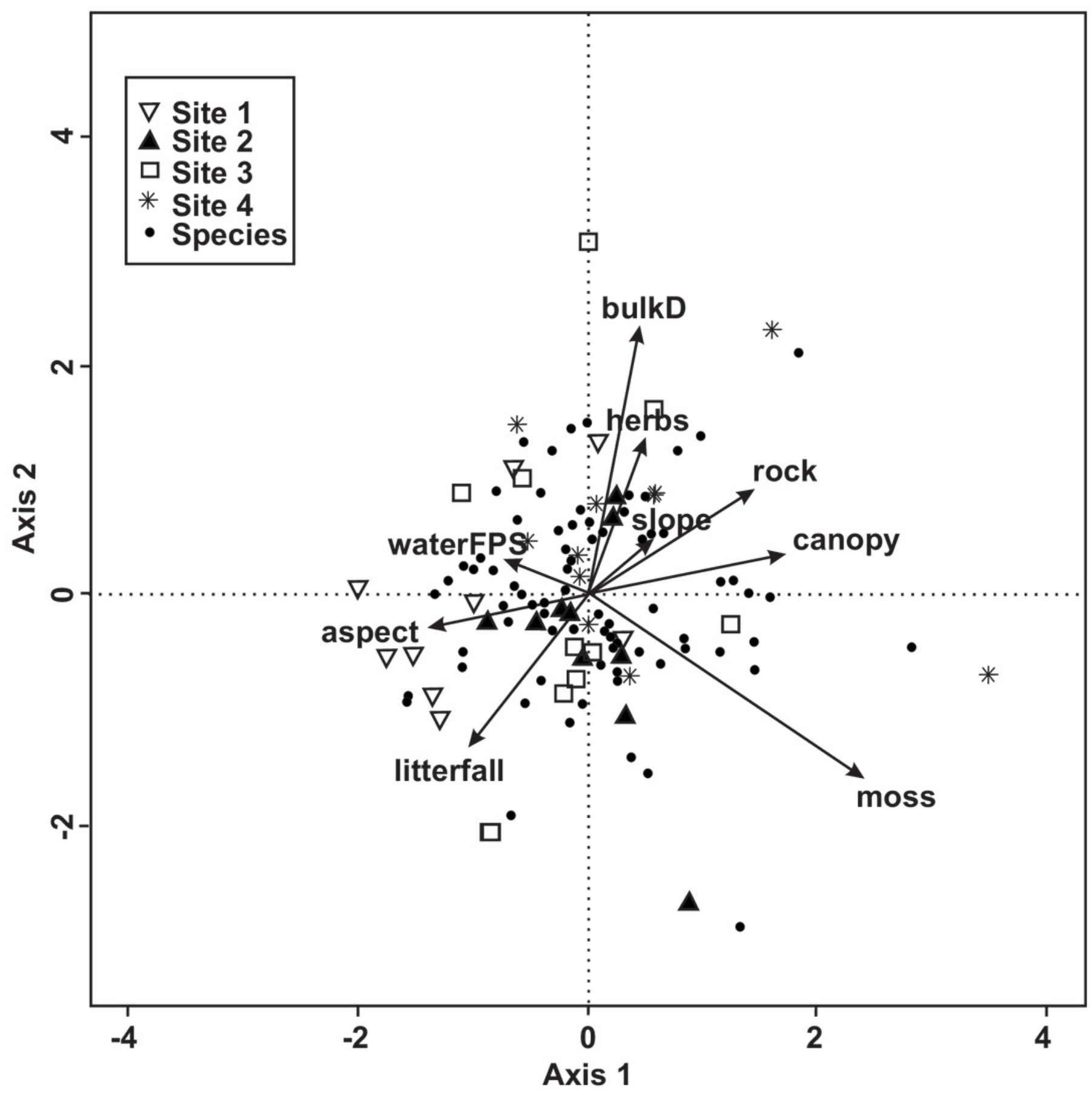


Figure 6

CCA for all the recorded macromycetes in the four study sites.

Vectors are vegetation structure explanatory variables: tree maximum height (treemaxH), tree average height (treeavH), tree basal area (treeBA), and tree density (treeDen). 


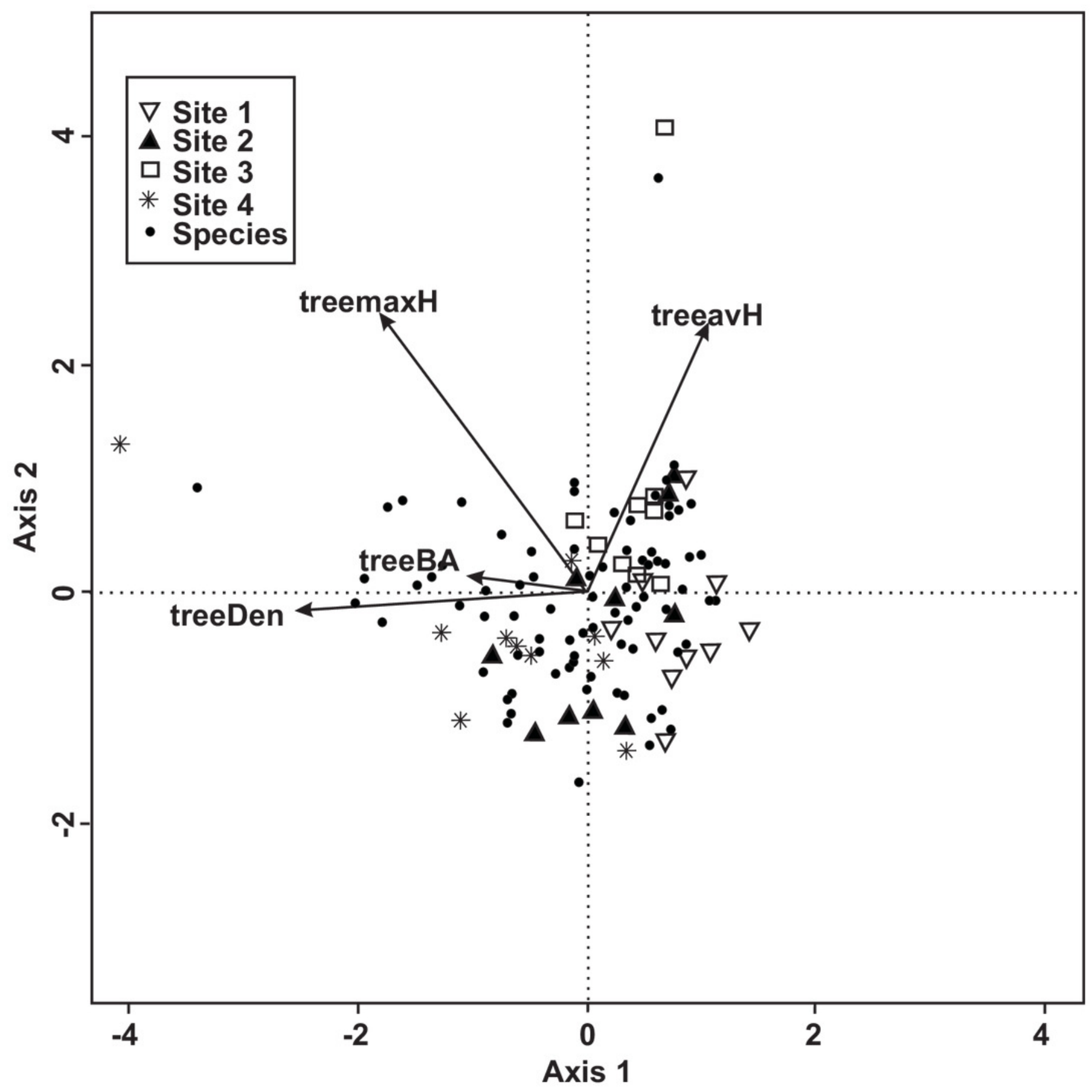




\section{Table $\mathbf{1}$ (on next page)}

Macromycete diversity and abundance in the study sites.

Macromyctete species richness, estimated richness (Jacknife 2), diversity and abundance in each studied site of the Mixteca region of Oaxaca, Mexico. 
1 Table 1. Macromyctete species richness, estimated richness (Jacknife 2), diversity, and abundance in each studied site of the Mixteca

2 region of Oaxaca, Mexico.

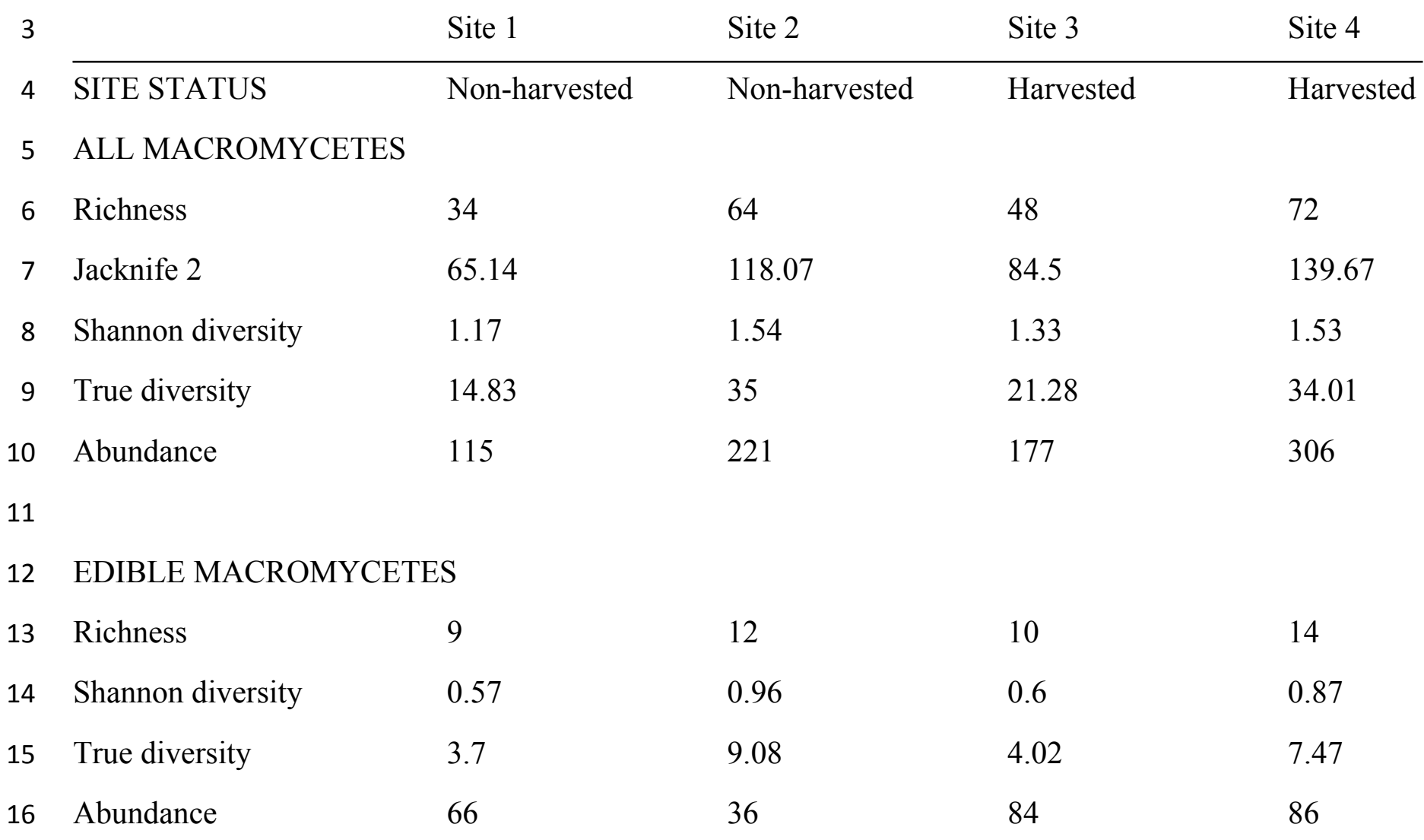




\section{Table 2 (on next page)}

Spearman correlation coefficients.

Spearman correlation coefficients ( $\rho$ ) between the species richness of macromycetes recorded in the studied area and the explanatory variables. 
1 Table 2. Spearman correlation coefficients $(\rho)$ between the species richness of macromycetes

2 recorded in the studied area and the explanatory variables.

3

4 Variable $\rho \quad$ p-value

5

6 Air temperature***

$-0.58 \quad 0.00008$

7 Relative air humidity***

$0.634 \quad 0.00001$

8 Soil temperature**

$-0.414 \quad 0.007$

9 Water content in soil

$\begin{array}{ll}0.098 & 0.545\end{array}$

10 Soil porosity

$\begin{array}{ll}-0.004 & 0.977\end{array}$

11 Soil pore space filled with water

$0.03 \quad 0.854$

12 Bulk density

$0.004 \quad 0.977$

$13 \mathrm{pH}$

0.14

0.388

14 Litterfall

$-0.068$

0.676

15 Rockiness

$\begin{array}{ll}0.169 & 0.294\end{array}$

16 Moss cover

0.214

0.184

17 Herbaceous*

0.336

0.033

18 Slope*

0.36

0.022

19 Aspect

$-0.099$

0.541

20 Canopy

$0.075 \quad 0.642$

21 Tree average height

0.158

0.327

22 Tree maximum height*

0.372

0.017

23 Tree basal area*

0.329

0.038

24 Tree density

0.172

0.285

25

26

$* \mathrm{p}<0.05, * * \mathrm{p}<0.01, * * * \mathrm{p}<0.001$ 


\section{Table 3(on next page)}

Chao-Jaccard similarity index.

Chao-Jaccard similarity index between pairs of sites based on the composition of macromycete species. 
1 Table 3. Chao-Jaccard similarity index between pairs of sites based on the composition of 2 macromycete species.

3

\begin{tabular}{llll}
4 & Pairs of sites & All macromycetes & Edible macromycetes \\
\cline { 2 - 3 } 5 & $1-2$ & 0.7 & 0.17 \\
6 & $1-3$ & 0.79 & 0.88 \\
7 & $1-4$ & 0.55 & 0.53 \\
8 & $2-3$ & 0.69 & 0.33 \\
9 & $2-4$ & 0.73 & 0.74 \\
10 & $3-4$ & 0.64 & 0.65
\end{tabular}

11

12

13

14

15

16

17

18

19 
